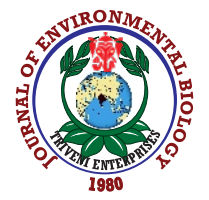

\title{
Chironomidae (Order: Diptera) diversity in relation to water quality of highland rivers at Cameron Highlands, Malaysia
}

\author{
A.K. Ahmad ${ }^{1 *}$, A. Hafizah ${ }^{1}$ and S.O. Sharifah Aisyah ${ }^{2}$ \\ ${ }^{1}$ Department of Earth Science and Environment, Faculty of Science and Technology, Universiti Kebangsaan Malaysia, Bangi, 43600, Malaysia \\ ${ }^{2}$ Faculty of Earth Science, Universiti Malaysia Kelantan, Jeli, 17600, Malaysia
}

*Corresponding Author Email : abas@ukm.edu.my

\begin{abstract}
Aim: This study aims to determine Chironomidae diversity and distribution in three small rivers at Cameron Highlands in relation to their response to water quality conditions.

Methodology: Fifteen sites from three rivers (Palas River, Pauh River and Bertam River) were chosen for water quality measurements and Chironomidae sampling. Water quality was analysed following APHA standard methods and chironomid was identified to genus level. The rivers were classified based on Malaysian's Water Quality Index (WQI) and macroinvertebrates diversity and distribution was analysed using diversity indices. Comparison between sites and river was undertaken using one-way ANOVA and chironomid appearance in relation to water quality was evaluated using Pearson correlation test.

Results: Chironomidae (Order: Diptera) distribution at high altitude rivers in Malaysia is not well documented although this group of insect has a wide range of distribution in tropical region. Based on Malaysian water quality index (WQI), result shows all rivers were in Class I. Although still in Class I, Bertam River has slight lower water quality due to higher ammoniacal nitrogen and total suspended solids. The diversity indices also demonstrate that Bertam Rivers was in stress conditions, and other two were in moderate conditions. Three subfamilies (Chironominae, Orthocladiinae and Tanypodinae) were recorded, which comprises of 1963 individuals. Tvetenia (Subfamily: Orthocladiinae) was the most dominant but only dominated Palas River and Pauh River. Another genus from Orthocladiinae (Crocotopus and Rheocrocotopus) also recorded dominant only in Palas River and Pauh River, but lesser in Bertam River. Only Polypedilum (Subfamily: Chironominae) which was second highest recorded, dominated in all rivers, even highest in Bertam River. Amongst dominant genus, only Polypedilum was found dominant in all rivers, others were only dominating Palas River and Pauh River only.

Interpretation: This findings exhibit wide range of adaptations and potential use of Polypedilum as biological indicator. Due to availability of incomplete keys, identification to species level cannot be undertaken. However, this study reveals thirteen different sub-group of Polypedilum based mouthpart organs, which represent different species for tropical ecosystems.

Key words: Biological indicator, Chironomids, Diversity indices, Freshwater, Polypedilum

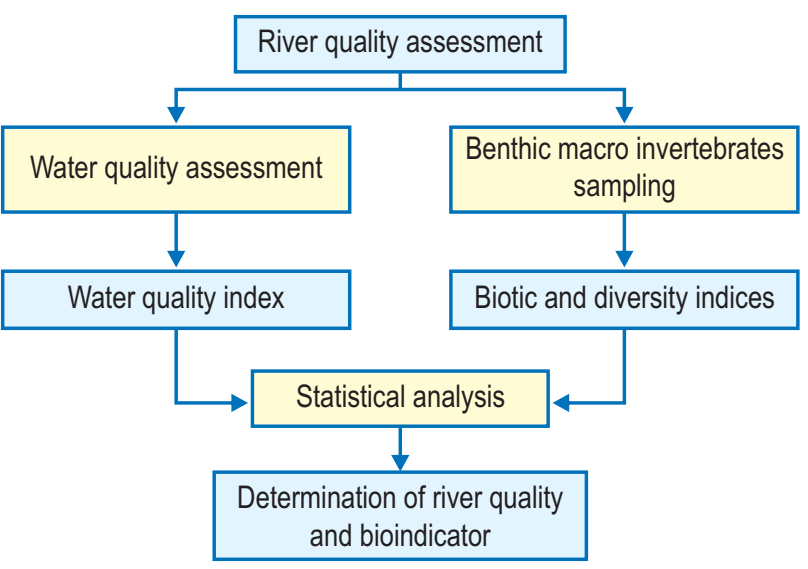

How to cite : Ahmad, A.K., A. Hafizah and S.O. Sharifah Aisyah: Chironomidae (Order: Diptera) diversity in relation to water quality of highland rivers at Cameron Highlands, Malaysia. J. Environ. Biol., 42, 824-831 (2021). 


\section{Introduction}

Chironomids has very high diversity and composition in freshwater ecosystems and more than 15000 species been recorded (Beermann et al., 2018). Chironomids exhibit wide range of adaptations to various types of habitat and water quality differences, therefore been recorded in most types of freshwater ecosystems (Serra et al., 2017). Chironomids compositions reported to represent one-third of world insect and most abundant in Holartic region.

Information of chironomids in Neotropical and Oriental regions was limited. However, several intensive studies on chironomids distribution in China, Japan and India were conducted, yet lack of taxonomic keys. Malaysia is one of the countries located within Oriental region and chironomids distribution was very scarce due to heterogeneity of the habitat types. There are four chironomids subfamilies reported in Malaysia namely Chironominae, Orthocladiinae, Tanypodinae dan Diamesinae. First Chironomidae recorded in Malaysia was Pentaneura batuensis (Tanypodinae:subfamily), Eusmittia cavernae (Orthocladiinae), Paratendipes inarmatus (Chironominae:subfamily) by Freeman, (1962) on his research at Batu Cave Selangor. Sub-family Diamensinae known to adapt to cooler region and Willassen (1988) reported Diamesa cranstoni at Kinabalu Mountain ecosystem at $3000 \mathrm{~m}$ asl. This finding proved possibility of discovering another species in Malaysia within highland ecosystems.

In Malaysia, studies on chironomids concentrated on the midges as bio-indicator to estimate the quality of the freshwater ecosystem (Prabhakaran et al., 2017; Azmi et al., 2016, Ahmad and Hanisah, 2018; Norhafizah-Azwa et al, 2018; Ahmad and Siti Hafizah 2017). Only few studies were carried out to estimate the chironomids diversity such as Al-Shami et al. (2010a, 2010b, $2011)$ in paddy field, Ahmad et al. $(2008,2014)$ and Appalasamy et al., 2018) in pristine rivers. Meanwhile, Zalela (2014) undertook a comprehensive study on chironomids diversity and distributions within upstream of Langat River in Selangor.

Chironomids distribution in highland ecosystems in Malaysia is not well documented. Malaysia has few aesthetic highland ecosystems such Genting Highland, Frasier Hill and Cameron Highlands. For instance, Cameron Highlands is assertively developed for tourism attractions and at the same times practiced agronomic practices for tea plantations and cash crops plants such as strawberry and vegetables. This study was conducted to fulfil information gap regarding chironomids diversity within highland ecosystems. Cameron Highlands have approximately 123 tributaries that flow water into three mian river namely Telom River, Bertam River and Lemoi River. Those streams and rivers provide sufficient habitat for aquatic macroinvertebrates.

\section{Materials and Methods}

Study sites: This study was conducted at two tributaries namely Pauh River and Palas River and Bertam River, which is one of main river in in Cameron Highlands. Even though only upstream of Bertam River was covered in this study, the study area is affected by many land use activities. Bertam River flows through various types of land use such agriculture (strawberry, flower, cash crops), residential and tourisms activities. which within order 2 and 3 river size. Pauh River (order 2) is flowing through protected forest that managed by Forestry Department. This river receives minimum anthropogenic impact compared to Bertam River and being used as recreational river. Since located within protected forest, the river has high canopy cover (app. 80\%). Palas River is an order 2 tributary flows downstream through tea plantation before confluent to Telom River. This river located within tea plantation area and therefore has lack of canopy cover. Geographical coordination and general physical characteristics of those rivers are presents in Table 1.

Water quality: Water quality has direct influence on chironomids present and distributions. In situ water quality measurements were undertaken for dissolved oxygen, $\mathrm{pH}$ and water temperature using pre-calibrated YSI Professional Series made in USA. Water samples were collected for chemical oxygen demand (COD), suspended solids (TSS) and ammoniacal-nitrogen analysis. A PVC coated BOD bottle was used to collected river water for biochemical oxygen demand $\left(\mathrm{BOD}_{5}\right)$ analysis. All water quality analyses were undertaken following standard method APHA (2012). The Malaysian water quality index proposed by department of environment the water quality twas used to determine rivers water quality.

Chironomids: Surber net (dimension $0.3 \mathrm{~m} \times 0.3 \mathrm{~m}$, pore size $250 \mu \mathrm{m}$ ) was used to collect chironomids in all stations due to shallow water. Collected materials were rinsed few times and preserved with ethanol $(70 \%)$ in sampling plastic bags. Five sampling stations were selected from each river and three replicates were collected from each station. In laboratory, samples were rinsed with tab water to remove preservative agent and chironomids samples were manually pickup using soft fine forceps and kept in 90\% ethanol. Chironomids samples were soak in $\mathrm{KOH}$ solution for 20 min and then neutralised with acetate acid. All samples were then prepared into permanent slide following Andersen et al. (2013).Chironomid samples were identified to the lowest taxonomic possible using Andersen et al. (2013), Cranston (2004;2013) and Epler (2010; 2014).

Data analysis: Malaysian wate quality index (WQI) was calculated using six selected formula and water quality comparison between rivers were examined using one-way ANOVA. The WQI formula is as below.

$$
\begin{aligned}
& \text { WQI }=0.22(\operatorname{siDO})+0.19(\operatorname{siBOD})+0.16(\text { siCOD })+0.15(\text { siAN })+ \\
& 0.16(\text { siTSS })+0.12(\operatorname{sipH}) \\
& \text { si }=\text { sub-index }
\end{aligned}
$$


Table 1: Geographical coordination and physical characteristics of studied rivers

\begin{tabular}{llll}
\hline Rivers & Bertam river & Pauh river & Palas river \\
\hline Substrates ${ }^{*}$ c: $p: s$ & $0: 10: 90$ & $10: 50: 40$ & $20: 40: 40$ \\
Canopy $(\%)$ & $<20$ & $>80$ & 0 \\
Water Depth $(\mathrm{m})$ & $0.1-0.3$ & $0.1-0.2$ & $0.2 \_0.4$ \\
River Width $(\mathrm{m})$ & $1-1.5$ & $1.5-4$ & $1-1.0$ \\
Velocity $\left(\mathrm{m} \mathrm{s} \mathrm{s}^{-1}\right)$ & $0.7 \pm 0.15$ & $0.4 \pm 0.07$ & $0.34 \pm 0.17$ \\
Altitude $(\mathrm{m})$ & $1490-1536$ & $1454-1484$ & $1562-1575$ \\
Geography Coordination & $101^{\circ} 23^{\prime} 09.3^{\prime \prime} \mathrm{E} 04^{\circ} 28^{\prime} 43.4^{\prime \prime} \mathrm{N}$ & $101^{\circ} 253^{\prime} 87.6^{\prime \prime} \mathrm{E} 04^{\circ} 28^{\prime} 89.0^{\prime \prime} \mathrm{N}$ & $101^{\circ} 25^{\prime} 22.5^{\prime \prime} \mathrm{E} 04^{\circ} 31^{\prime} 69.0^{\prime \prime} \mathrm{N}$ \\
\hline
\end{tabular}

*Note: $c($ 'cobble') = large stone, $p=$ pebble, $s=$ sand

The Shannon diversity index was calculated to estimate chironomid richness and composition in highland rivers. The Pielou Evenness Index and Margalef Richness Index were also calculated to exhibits domination and evenness within studied rivers. The similarity and differences of indices between rivers were tested using Pearson correlation and one-way ANOVA after confirmation of normal distributions respectively.

\section{Results and Discussion}

Water quality: In average, the water temperature for all rivers was $17.9 \pm 0.05^{\circ} \mathrm{C}$. highest water temperature was detected at Palas River that located in tea plantation. With small water body and least canopy cover make highest water temperature in Palas River. Similar result exhibits by Bertam River as second highest in river water temperature (Table 2). Water temperature at highland river obviously much lower than lowland rivers, which normally ranges between $25^{\circ} \mathrm{C}$ to $30^{\circ} \mathrm{C}$. Altitude with canopy cover and water depth determine river water temperature. For example, water temperature of lowland river was ranging between $26^{\circ} \mathrm{C}$ and $27^{\circ} \mathrm{C}$ (Fawaz et al., 2013 and Ahmed et al., 2020). Similar pattern was obtained for organic substances parameters such as biochemical oxygen demand $\left(\mathrm{BOD}_{5}\right)$ and $\mathrm{COD}$ concentrations. Based on Malaysian National Water Quality Standard, both parameters classify all rivers into Class I. The total suspended solids (TSS) in all rivers also low and classified all rivers in class I. However, even though still in class I, Bertam River exhibits slightly lower quality compared to others especially on TSS. As main tributary, this river receives water from smaller order tributaries which carry high TSS concentrations due to assertive agriculture activities. The one-way ANOVA test indicates insignificant different each parameter between rivers $(p>0.05)$. Ammoniacal nitrogen was detected highest in Bertam River which expected due to agriculture wastes.
The Malaysian Water Quality Index (WQI) was calculated based on six selected parameters and results were presented in Fig. 1. Pauh River and Palas River were classified as in Class I based on Malaysian Water Quality Standard (NWQS), but Bertam River was in Class II due to high TSS concentration in water body. However, WQI index value (87.5), indicates all studied rivers are in clean condition includes Bertam River even though contains TSS concentrations. Uncontrolled land opening for agriculture predicted to cause high sedimentation in Bertam River especially after rain.

Chironomidae composition and distribution: A total of 1963 chironomid individual were recorded which consists of three subfamilies and 29 genus. Chironomidae represented by three subfamilies namely Chironominae, Orthocladiinae and Tanypodinae. Subfamily Chironominae characterized by two tribes Chironomini and Tanytarsini with 325 and 241 individuals respectively. Subfamily Orthocladiinae represented by 15 families (1315 ind) and subfamily Tanypodinae was not identified to lower taxa due to insufficient key available and 42 individuals

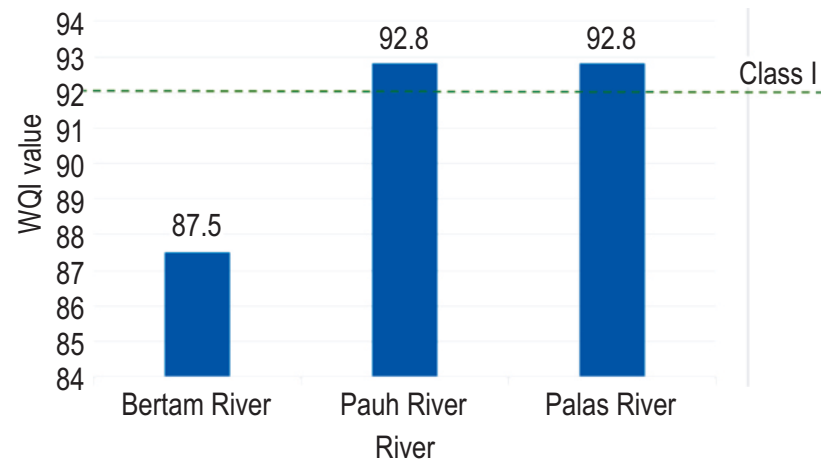

Fig. 1 : WQI comparison between three rivers

Table 2: Water quality for three studied rivers in Cameron Highlands

\begin{tabular}{llllllll}
\hline River & Temp. $\left({ }^{\circ} \mathrm{C}\right)$ & $\mathrm{pH}\left(\mathrm{mgl}^{-1}\right)$ & $\mathrm{DO}\left(\mathrm{mgl}^{-1}\right)$ & $\mathrm{BOD}_{5}\left(\mathrm{mgl}^{-1}\right)$ & $\mathrm{COD}\left(\mathrm{mgl}^{-1}\right)$ & $\mathrm{TSS}\left(\mathrm{mgl}^{-1}\right)$ & $\mathrm{NH}_{3}-\mathrm{N}\left(\mathrm{mgl}^{-1}\right)$ \\
\hline Bertam River & $18.4 \pm 0.05$ & $7.19 \pm 0.11$ & $6.9 \pm 0.23$ & $0.49 \pm 0.44$ & $5.92 \pm 4.53$ & $29.41 \pm 17.46$ & $0.23 \pm 0.16$ \\
Pauh River & $17.9 \pm 0.05$ & $7.24 \pm 0.03$ & $7.23 \pm 0.05$ & $0.41 \pm 0.06$ & $6.01 \pm 1.14$ & $5.14 \pm 2.25$ & $0.09 \pm 0.04$ \\
Palas River & $19.2 \pm 0.09$ & $7.24 \pm 0.06$ & $7.13 \pm 0.10$ & $0.64 \pm 0.06$ & $5.37 \pm 1.26$ & $3.09 \pm 0.85$ & $0.10 \pm 0.02$ \\
\hline
\end{tabular}


were recorded. Orthocladiinae and Chironominae exhibit quite similar taxa richness between rivers, and few genus from each subfamily showed domination (Table 3 ).

Chironomids density between three rivers were tested using one-way ANOVA and result indicates homogeneity of composition between rivers $(p=0.299, \alpha=0.05)$. Palas River and Pauh River have approximately even chironomids density, and both were higher than Bertam River. Genus composition from all subfamilies are presented in Fig. 2. All dominant genus were present in all rivers, but with lower composition in Bertam River except Polypedilum.

Tvetenia (subfamily: Orthocladiinae) was the most dominant genus recorded but only one individual was recorded in Bertam River. Polypedilum is second dominant genus and found highest in Bertam River. Rheotanytarsus, Eukiefferiella, Paracricotopus and Cricotopus were well distributed between rivers but but lowest in Bertam River.

Diversity indices based on chironomids data for all rivers are presented in Table 4. Shannon diversity was lowest at Bertam River (0.971) and 1.788 and 1.715 for Pauh River and Palas River respectively. Bertam River also exhibits lowest for Pielou evenness and Margalef Richness index. This simply explains lower quality of Bertam River ecosystem based on chironomid populations.

High altitude rivers reported to have higher Orthocladiinae taxa and similar result was recorded in Palas River and Pauh River. Hamerlik et al. (2018) in his study at high altitude streams also found Orthocladiinae as dominant subfamily and lack of Chironominae, which might be largely related to the preference for tropical and subtropical lowlands that exhibited by most members of this subfamily. Ahmad and Hanisah (2018) in their study at high altitude river in tropical region found Chironominae as most dominant subfamily followed by Tanypodinae and Orthocladiinae.

This study found Bertam River was dominated by Polypedilum (subfamily: Chironominae). As regards to NWQS and WQI indices, Bertam River has the lowest as compared to

Table 3: Checklist of Chironomidae in three studied rivers

\begin{tabular}{|c|c|c|c|c|}
\hline & \multicolumn{4}{|c|}{ River } \\
\hline & Bertam river & Pauh river & Palas river & Total \\
\hline \multicolumn{5}{|l|}{ Subfamily: Chironominae } \\
\hline \multicolumn{5}{|l|}{ Tribe: Chironomini } \\
\hline Polypedilum & 142 & 48 & 134 & 324 \\
\hline Cryptochironomus & 0 & 1 & 0 & 1 \\
\hline Chironomus & 1 & 16 & 0 & 17 \\
\hline Demicryptochironomus & 0 & 5 & 1 & 6 \\
\hline Harnischia & 0 & 2 & 10 & 12 \\
\hline Kompleks Harnischia genus C & 0 & 1 & 0 & 1 \\
\hline Microtendipes & 0 & 1 & 0 & 1 \\
\hline \multicolumn{5}{|l|}{ Tribe: Tanytarsini } \\
\hline Rheotanytarsus & 19 & 164 & 54 & 237 \\
\hline Tanytarsus & 0 & 4 & 0 & 4 \\
\hline \multicolumn{5}{|l|}{ Subfamily: Orthocladiinae } \\
\hline Cricotopus & 24 & 4 & 138 & 166 \\
\hline Rheocricotopus & 0 & 129 & 9 & 138 \\
\hline Tvetenia & 1 & 348 & 435 & 784 \\
\hline Eukiefferiella & 5 & 5 & 70 & 80 \\
\hline Cardiocladius & 0 & 0 & 23 & 23 \\
\hline Heleniella & 0 & 5 & 0 & 5 \\
\hline Limnophyes & 0 & 0 & 2 & 2 \\
\hline Paracricotopus & 4 & 28 & 56 & 88 \\
\hline Parametriocnemus & 0 & 9 & 3 & 12 \\
\hline Paratrissocladius & 0 & 8 & 0 & 8 \\
\hline Onconeura & 0 & 1 & 0 & 1 \\
\hline Synorthocladius & 0 & 3 & 0 & 3 \\
\hline Thienemanniella & 1 & 0 & 3 & 4 \\
\hline Orthocladiinae genus 1 & 0 & 0 & 4 & 4 \\
\hline Subfamily: Tanypodinae & 0 & 40 & 2 & 42 \\
\hline Total individual & 197 & 822 & 944 & 1963 \\
\hline No of Taxa & 14 & 8 & 11 & \\
\hline
\end{tabular}




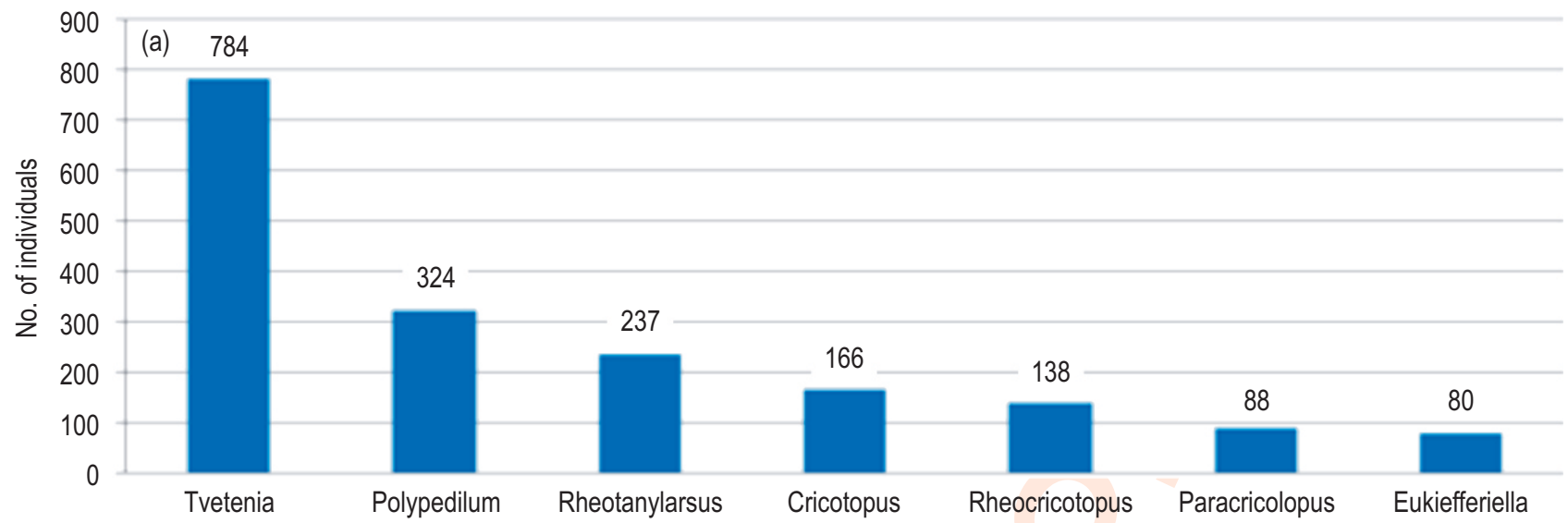

Genus

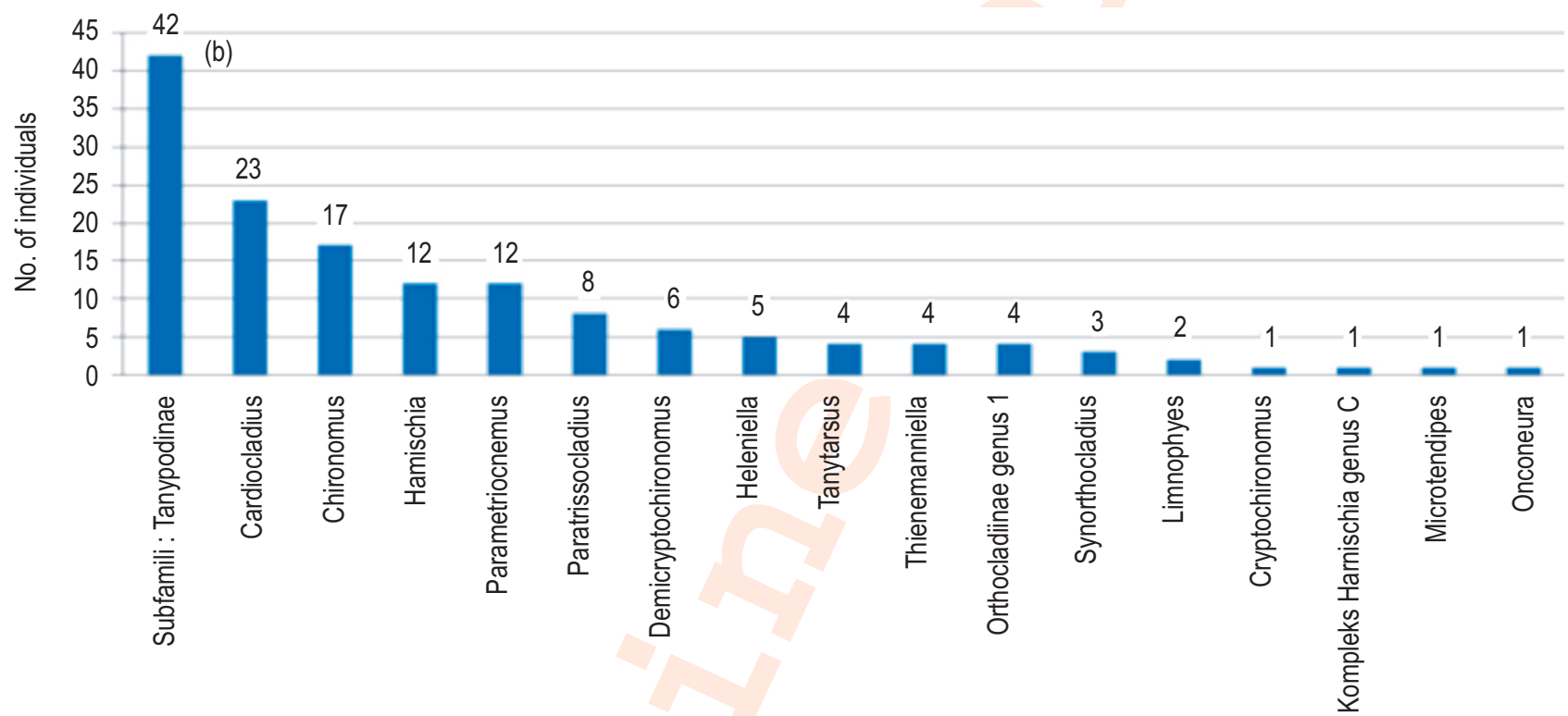

Genus

Fig. 2 : Taxa composition for three studied rivers: (a) Taxa composition more than 50 individuals and (b) Taxa composition less than 50 individuals.

Palas River and Pauh River. Bertam River contains high suspended solids due to aggressive land opening. However, Polypedilum was recorded most dominant in this river. The genus reported to have high environmental gradient adaptations (Sriariyanuwath et al., 2015) and has many feeding behaviours (Beermann et al, 2018; Leite-Rossi et al., 2019). Previous studies indicate this genus is tolerable to organic concentrations (Bazzanti, 2000; Garcia and Laville, 2000; Leszczyńska et al., 2019). Instead of having turbid water, Bertam River also found to have higher ammoniacal. This study indicates good adaptation of this genus to turbid water and high ammoniacal nitrogen concentrations. It's important to identify the genus to species level to confirm biological indicator species. However, this study unable to identify the genus to lower taxonomic level due to uncomplete keys available for species identification. However, based on morphological differences, this study has discovered thirteen groups of Polypedilum, Scarcity in tropical region taxonomic key limits the study to propose a specific biological indicator species.

Chironominae and Orthocladiinae diversity and composition vary with altitude and water temperature change (Helson et al., 2006; Garay et al., 2020). Instead of those factors, anthropogenic activities also affect those subfamilies. Cranston (2004) reported that Polipedilum is very diverse in tropical region. Bertam River which affected by agriculture activities and has higher organic substances was dominated by Polypedilum and this genus was reported tolerant to organic contaminations (Bazzanti, 2000; Kranzfelder and Ferrington, 2018; Montes et al., 2020). 


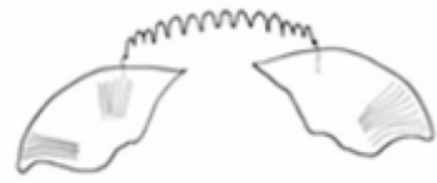

(i) group $\mathrm{A}$

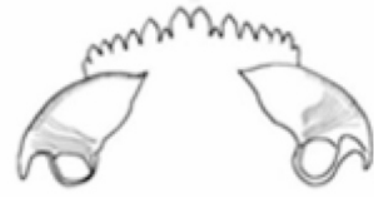

(iv) group D

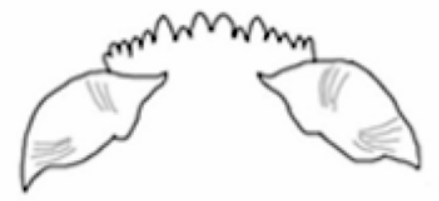

(vii) group G

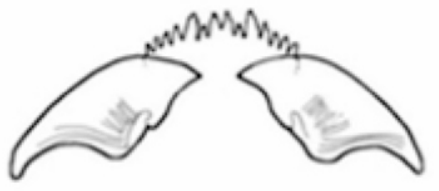

(x) group J

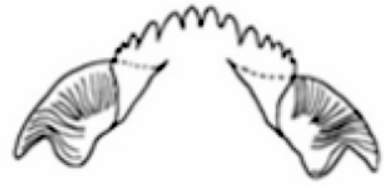

(ii) group B

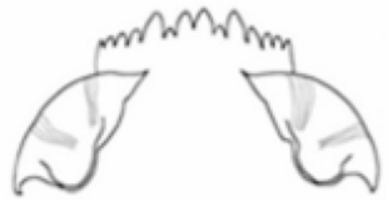

(v) group E

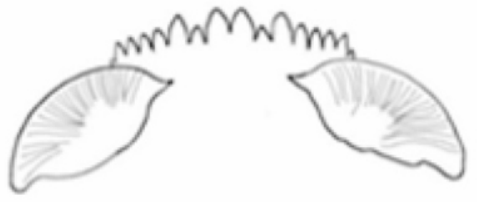

(viii) group $\mathrm{H}$

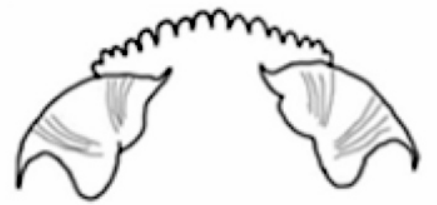

(xi) group $\mathrm{K}$

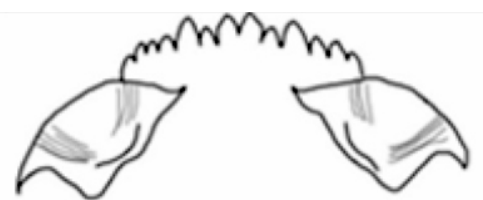

(iii) group C

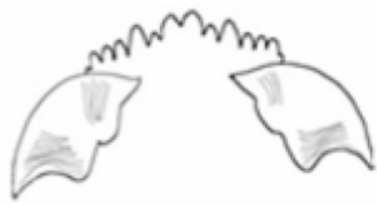

(vi) group F

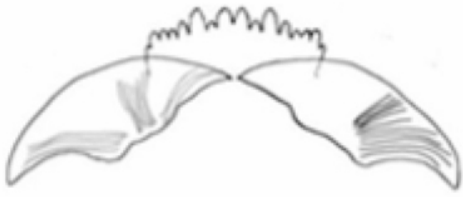

(ix) group I

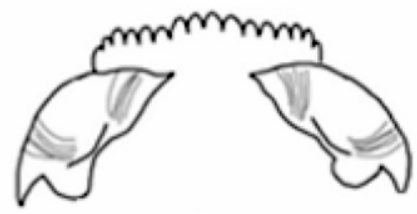

(xii) group L

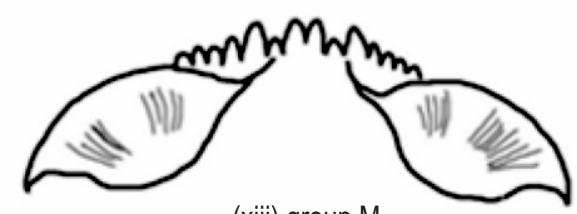

(xiii) group M

Note : drawing not to scale

Fig. 3 : Variety of Polypedilum spp. head capsule discovered in this study.

Taxonomic from subtropical and tropical region is still scarce with only few species were well elaborated (Cranston et al., 2013). This genus reported abundant in sandy substrates due to its feeding habit (collectors). Bertam River substrates dominated by sand (90\%) and therefore prefered by Polypedilum group. This study has recorded 324 individuals and almost half were in Bertam River. Ventromental plate morphology was the easiest way to differentiate from another genus (Fig. 3). Polypedilum also recognised by having five segmented antennae, mandible with dark dorsal teeth and two inner teeth. This study reveals thirteen groups of Polypedilum which indicates possibility to establish new species from Polypedilum genus. There were few different names were misused for same organism and existing sub-genus is not suitable to be used for certain larval.

Chironomids are important agent for biological monitoring worldwide due to their wide range of tolerant and this group has been explored as biological indicator for water quality in develop countries (Lencioni et al., 2012; Czechowski et al., 2020). This study reveals the potential of Polypedilum as biological indicator at high altitude ecosystems. At genus level, Polypedilum exhibits large range of tolerant and therefore it is 
Table 4: Diversity indices for three studied rivers

\begin{tabular}{llll}
\hline Indices & Bertam River & Pauh River & Palas River \\
\hline Shannon diversity $(\mathrm{H})$ & 0.971 & 1.788 & 1.715 \\
Pielou evenness $(\mathrm{E})$ & 0.47 & 0.59 & 0.633 \\
Margalef richness $\left(\mathrm{D}_{\text {M9 }}\right)$ & 1.32 & 2.83 & 2.04 \\
\hline
\end{tabular}

important to identify to species level for river quality assessment purpose. Similar result was reported by Zalela (2014) on her study at low altitude rivers, where Polypedilum also dominated low altitude rivers (Chertoprud et al., 2018). Only at species level, a true biological indicator could be confirmed because within a single genus, species may respond in a distinct manner to environmental changes (Lenat and Resh, 2001; Beermann et al, 2018).

In conclusion, the study on hydrology at Cameron Highland demonstrates that upstream streams were not affected significantly by anthropogenic activities as compared to middle stretch or downstream area. Even though Bertam River exhibits lower water quality compared to Pallas and Pauh River, studied area (Upstream of Palas River, Pauh River and Bertam River) are still within class I water quality. Similar results were observed for chironomid composition and diversity. Tvetenia (Subfamily: Orthocladiinae) exhibits domination at highland and good water quality. Only Polypedilum exhibits good tolerant to lower water quality river (Bertam River). This study reveals that genus Polypedilum at studied rivers has thirteen different groups below genus level that makes large range water quality tolerant. Therefore, species confirmation is very crucial for identifications of biological indicator at species level especially for Polypedilum spp.

\section{Acknowledgments}

We express our heartfelt gratitude to various people involved in this study for their tireless help during fieldwork. We are grateful to the Department of Earth Science and Environment, Faculty Science and Technology, Universiti Kebangsaan Malaysia for providing laboratory facilities to conduct this research.

\section{Add-on Information}

Authors'contribution: A.K. Ahmad: Main author and supervisor of the project; A. Hafizah: Identification of chironomids; S.O. Sharifah Aisyah: Statistical analysis and coresearcher.

Research content : The research content of manuscript is original and has not been published elsewhere.

Ethical approval : NotApplicable
Conflict of interest : The authors declare that there is no conflict of interest.

\section{Data from other sources : NotApplicable}

Consent to publish : All authors agree to publish the paper in Journal of Environmental Biology.

\section{References}

Ahmad, A.K., A.B. Idris, M.S. Othman, H. Salwana and H. Hamisah: A preliminary survey of chironomids diversity at the headwater of Langat River, Selangor. Serangga, 13, 1-18 (2008).

Ahmad, A.K., Z.A. Aziz and M. Shuhaimi-Othman: Chironomid spatial distribution within the upstream of Sungai Langat Catchment. Sains Malays., 43, 1657-1663 (2014).

Ahmad, A.K. and S.H. Ahmad: A first record of Fissimentum Cranston and Nolte (Diptera: Chironomidae) in Peninsular Malaysia. Serangga, 22, No. 2 (2017).

Ahmad, A.K. and H. Ibrahim: Potensi chironomidae sebagai penunjuk biologi di sungai rekreasi terpilih Janda Baik, Pahang, semenanjung Malaysia. Serangga, 23, No. 2 (2018).

Ahmed, M.F. and M. Mazlin: Treated water quality based on conventional method in Langat River Basin, Malaysia. Environ. Earth Sci., 79, 116 (2020).

Al-Shami, S.A., C.S.M. Rawi, A.H. Ahmad, S.A. Hamid and S.A.M. Nor: Influence of agricultural, industrial, and anthropogenic stresses on the distribution and diversity of macroinvertebrates in Juru River Basin, Penang, Malaysia. Ecotoxicol. Environ. Saf., 74, 1195-1202 (2011).

Al-Shami, S.A., C.S.M. Rawi, A. Hassan Ahmad and S.A.M. Nor: Distribution of Chironomidae (Insecta: Diptera) in polluted rivers of the Juru River Basin, Penang, Malaysia. J. Environ. Sci. (China), 22, 1718-1727 (2010).

Al-Shami, S.A., M.R.C. Salmah, A.A. Hassan and M.N.S. Azizah: Temporal distribution of larval Chironomidae (Diptera) in experimental rice fields in Penang, Malaysia. J. Asia Pac. Entomol., 13, 17-22 (2011).

Andersen, T., P.S. Cranston and J.H. Epler: Chironomidae of the Holarctic region keys and diagnoses - Larvae. Insect Syst. Evol., Suppl., 66, 1-573 (2013).

APHA: Standard methods for the examination of water and wastewater. $19^{\text {th }}$ Edn., American Public Health Association, Washington D.C., USA(2012).

Appalasamy, S., A. Nivaarani, S. Sayzwani and E.R. Aweng. Physicochemical water quality and macroinvertebrate distribution along Sungai Asah in Pulau Tioman, Johor, Malaysia. Songklanakarin J. Sci. Technol., 40, No. 6 (2018).

Azmi, W.A. and A.G. Hoon: Aquatic insect communities in relation with water quality of selected tributaries of Tasik Kenyir Terengganu. $J$. 
Sustain. Sci. Manag., 11, (2016).

Bazzanti, M.: Ecological requirements of chironomids (Diptera: Chironomidae) on the soft bottom of the river Arrone, Central Italy. J. Freshw. Ecol., 15, 397-409 (2000).

Beermann, A.J., V.M. Zizka, E. Vasco, B. Viktor and L. Florian: DNA metabarcoding reveals the complex and hidden responses of chironomids to multiple stressors. Environ. Sci. Eur., 30, 28 (2018).

Chertoprud, M.V., D.M. Palatov and E.S. Chertoprud: Rheophilic macrozoobenthos communities of the Southern Himalayas. Inland Water Biology, 11, 435-447 (2018).

Cranston, P.S.: Insecta: Diptera, Chironomidae. In: The freshwater invertebrates of Malaysia and Singapore (Eds.: C.M. YuleAnd H.S. Yong). Academy of Sciences, Malaysia., pp. 710-734 (2004).

Cranston, P.S.: The larvae of the holarctic Chironomidae (Diptera) morphological terminology and key to subfamilies. In: The larvae of Chironomidae (Diptera) of the Holarctic Region - Keys And Diagnoses (Eds.: T. Andersen, P.S. Cranston and J.H. Epler). Insect Syst. Evol., Suppl., 66, 13-23 (2013).

Czechowski, P., I.S. Mark, M. Chris and W. Philip. Steps towards a more efficient use of chironomids as bioindicators for freshwater bioassessment: Exploiting Edna And Other Genetic Tools. Ecological Indicators, 110, 105868 (2020).

Epler, J.H., T. Ekrem and P.S. Cranston: The larvae of chironominae of holarctic region- keys and diagnoses. In: The larvae of Chironomidae (Diptera) of the holarctic region - keys and diagnoses (Eds.: T. Andersen, P.S. Cranston and J.H. Epler). Insect Syst. Evol. Suppl., 66, 387-557 (2010).

Epler, J.H.: Identification guide to the larvae of the tribe Tanytarsini (Diptera: Chironomidae) in florida. Department of Environmental Protection, Division of Environmental Assessment and Restoration Tallahassee, Florida, Usa (2014).

Fawaz, A., M.S. Othman and M.B. Gasim: Water quality assessment of the Semenyih River, Selangor, Malaysia. J. Chem., 2013, 1-10 (2013).

Freeman, P.: Chironomidae from the batu caves, malaya (Diptera: Nematocera). Pac. Insects, 4, 129-131 (1962).

Garay G.N., A. Rodríguez, C. Paggi and E.S. Erica: Chironomidae assemblages at different altitudes in northwest argentina: The role of local factors. Anais Da Academia Brasileira De Ciências, 92 (2020).

Garcia, X.F. and H. Laville: First inventory and faunistic particularities of the chironomid population from a 6th order section of the sandy River Loire (France). Arch. Hydrobiol., 147, 465-484 (2000).
Hamerlik, L., F. Laurindo Da Silva and D. Jacobsen: Chironomidae (Insecta: Diptera) of Ecuadorian high altitude streams: A survey and illustrated key. Fla. Entomol., 101,663-675(2018).

Helson, J.E., D.D. Williams And T. Dorothea: Larvae chironomid community organization in four tropical rivers: Human impacts and longitudinal zonation. Hydrobiologia, 599, 413-431 (2006).

Kranzfelder, P. and L.C. Ferrington: Chironomidae (Diptera) species diversity of estuaries across a land use gradient on the Caribbean Coast of Costa Rica. Revi. De Biolo. Tropi., 66, 11181134 (2018)

Leite-Rossi, L.A., H.H.L. Saulino, E.M. Shimabukuro, M.B. CunhaSantino and S. Trivinho-Strixino: Shredder chironomid diets are influenced by decomposition rates of different leaf litter species. Neotrop. Entomol., 48, 38-49 (2019).

Leszczyńska, J., M. Grzybkowska, Ł. Głowacki and M. Dukowska. Environmental variables influencing chironomid assemblages (Diptera: Chironomidae) in lowland rivers of Central Poland. Environ. Entomol., 48, 988-997 (2019).

Lenat, D.R. And V.H. Resh: Taxonomy And Stream Ecology - The benefits of genusand species-level identifications. J. North $A m$. Benthol. Soc., 20, 287-298 (2001).

Lencioni, V., L. Marziali And B. Rossaro: Chironomids as bioindicators of environemental quality in mountain springs. Freshw. Sci., 31, 525$541(2012)$

Montes, D.O., Fernanda, S. T. Marcela, M. Julieta, M. Sofia Plastani and L. Cecilia. The chironomids (Diptera: Chironomidae) of shallow lakes of the humid pampa region, Argentina: An approach to paleoproductivity reconstruction. Palaios, 35, 191-200 (2020)

Nurhafizah-Azwa, S. and A.K. Ahmad: Biodiversity of benthic macroinvertebrates in Sungai Kisap, Langkawi, Kedah, Malaysia. J. Trop. Reso. Sustain. Sci., 6, 36-40 (2018).

Prabhakaran, K., R. Nagarajan, F.M. Franco and A.A. Kumar: Biomonitoring of Malaysian aquatic environments: A review of status and prospects. Ecohydrol. Hydrobiol., 17, 134-147 (2017).

Serra, S.R.Q., M.A.S. Graça and S. Dolédec: Chironomidae of the holarctic region: A comparison of ecological and functional traits between North America and Europe. Hydrobiologia, 794, 273-285 (2017)

Sriariyanuwath, E., N. Sangpradup and C. Hanjavanit: Diversity of chironomid larvae in relation to water quality in the Phong River, Thailand. Aquacult. Aquarium Conserv. Legis., 8, 933-945 (2015).

Willassen, E.: A new oriental species of diamesa meigen (Diptera: Chironomidae). Aquat. Insects, 10, 221-225 (1988). 